\title{
Effects of genetic modifications to flax (Linum usitatissimum) on arbuscular mycorrhiza and plant performance
}

\author{
Magdalena Wróbel-Kwiatkowska • Katarzyna Turnau • \\ Katarzyna Góralska • Teresa Anielska • Jan Szopa
}

Received: 22 August 2011 / Accepted: 14 December 2011 / Published online: 5 January 2012

(C) The Author(s) 2012. This article is published with open access at Springerlink.com

\begin{abstract}
Although arbuscular mycorrhizal fungi (AMF) are known for their positive effect on flax growth, the impact of genetic manipulation in this crop on arbuscular mycorrhiza and plant performance was assessed for the first time. Five types of transgenic flax that were generated to improve fiber quality and resistance to pathogens, through increased levels of either phenylpropanoids (W92.40), glycosyltransferase (GT4, GT5), or PR2 beta-1,3-glucanase (B14) or produce polyhydroxybutyrate (M50), were used. Introduced genetic modifications did not change the degree of mycorrhizal colonization as compared to parent cultivars Linola and Nike. Arbuscules were well developed in each tested transgenic type (except M50). In two lines (W92.40 and B14), a higher abundance of arbuscules was observed when compared to control, untransformed flax plants. However, in some cases (W92.40, GT4, GT5, and B14 Md), the mycorrhizal dependency for biomass production of transgenic plants was slightly lower when compared to the original cultivars. No significant influence of mycorrhiza on the photosynthetic activity of transformed lines was found, but in most cases $\mathrm{P}$ concentration in mycorrhizal plants remained
\end{abstract}

\footnotetext{
M. Wróbel-Kwiatkowska

Department of Pharmaceutical Biology and Botany,

Medical University of Wrocław,

Al. J. Kochanowskiego 10,

51-601 Wrocław, Poland

K. Turnau $(\triangle) \cdot K$. Góralska $\cdot$ T. Anielska

Institute of Environmental Sciences, Jagiellonian University,

Gronostajowa 7,

30-387 Kraków, Poland

e-mail: katarzyna.turnau@uj.edu.pl

J. Szopa

Faculty of Biotechnology, University of Wrocław,

Przybyszewskiego 63/77,

51-148 Wrocław, Poland
}

higher than in nonmycorrhizal ones. The transformed flax lines meet the demands for better quality of fiber and higher resistance to pathogens, without significantly influencing the interaction with AMF.

Keywords Mycorrhiza · Linum usitatissimum · Transgenic flax $\cdot$ Plant performance

\section{Introduction}

Although genetically modified plants (GMPs) have already been accepted by several countries for use in the open field (Liu 2010), there is still a paucity of knowledge on the potential hazards of releasing such organisms into nature, including their potential impact on non-target microbiota (Giovannetti et al. 2005; Liu 2010; Stefani and Hamelin 2010). Arbuscular mycorrhizal fungi (AMF) are among the most common microbiota in soils, and plant dependency on AMF communities is essential and extensive in both natural and disturbed habitats (Van der Heijden et al. 1998; Smith and Read 2008). AMF can be crucial in low-input agriculture, while in strongly fertilized soil they can be totally ineffective or absent (Boyetchko 1996; He and Nara 2007).

As recently reviewed by Stefani and Hamelin (2010), GMPs can alter or not affect mycorrhizal development or colonization rates. Negative effects have been observed in Bt transgenic rice (Ren 2006), corn, and defensinexpressing aubergine (Turrini et al. 2004a). This involved reduced presymbiotic hyphal growth and development of appressoria (Turrini et al. 2004a) and reduced root colonization and spore density in rhizosphere soil (Ren 2006). Over half of the studies showed no effect of Bt transgenic plants on AMF, but to avoid potential risks it nevertheless seems crucial to test every newly developed GMP for its 
effect on arbuscular mycorrhizal association before released into the field.

Genetically modified (GM) flax lines have been created as a model for studying the role of antioxidants and to improve antifungal resistance and retting efficiency for the production of fiber-rich material (Szopa et al. 2009; Gredes et al. 2010; Skórkowska-Telichowska et al. 2010, Czemplik et al. 2011). Studies on the effect of genetic modifications of flax on plant-AMF interactions are important as GM flax starts to be cultivated in the field and the commercial demand for this crop is large. GM flax lines pose little environmental risk because their seed production and adventitious presence among subsequent crops and yield are relatively easy to control (Jhala et al. 2010). Nevertheless, mechanisms that the plant uses against pathogens can have deleterious effects also on mutualistic symbionts (Whipps 2004). Thus, the aims of the present study were to investigate the effect of different genetic modifications of flax (Linum usitatissimum) on root colonization by Glomus intraradices and compare mycorrhizal dependency of individual lines.

\section{Materials and methods}

Five types of transgenic flax (Table 1) were used in the present study. The transgenic lines have been generated from Linola and Nike cultivars and characterized previously (Wróbel et al. 2004; Wróbel-Kwiatkowska et al. 2004; Łukaszewicz et al. 2004a, b; Lorenc-Kukuła et al. 2005, 2009). Three have increased levels of either phenylpropanoids (W92.40), pathogenesis-related PR-2 protein (B14), or $\beta$-hydroxybutyrate polymer (M50). W92 flax plants ( $L$. usitatissimum cv. Linola) were obtained by overexpression of three Petunia hybrida genes from the flavonoid biosynthesis pathway encoding chalcone synthase, chalcone isomerase, and dihydroflavonol reductase. The B14 transgenic plants are obtained from fibrous cultivar of flax (Nike) and have ectopic expression of a defense-related potato $\beta-1,3-$ glucanase gene (PR-2). M50 plants are also derived from cultivar Nike and transformed with Ralstonia eutropha genes coding for $\beta$-ketothiolase (phbA), acetoacetyl-CoA reductase $(\mathrm{phbB})$, and $\mathrm{PHB}$ synthase $(\mathrm{phbC})$ for poly- $\beta$ hydroxybutyrate (PHB) synthesis. Two other plant lines (GT4, GT5) derived from Linola cultivar overproduce glycosyltransferase, resulting in the accumulation of proanthocyanin, lignan, phenolic acid, and unsaturated fatty acids in seeds. Plants of an MB type were also obtained, by classical crossing of lines $\mathrm{M}$ and $\mathrm{B}$. All these transgenic flax lines show improved resistance to common flax pathogens such as Fusarium oxysporum and/or Fusarium culmorum, which cause diseases such as vascular wilt, corm rot, root rot, or damping-off (Armstrong and Armstrong 1981; Jones 1991).

Culture conditions of mycorrhizal and nonmycorrhizal plants

Seeds of the GM flax lines were germinated on wet filter paper in Petri dishes at approximately $20^{\circ} \mathrm{C}$. Five-day old seedlings ( $n=5$ to 9 depending on the line) were transferred into $800 \mathrm{ml} \varnothing 13-\mathrm{cm}$ pots with sterile substratum composed of a mixture of garden soil (Rolex, containing peat, sand, pine bark, compost enriched with organic fertilizers and dolomite), sand, and expanded clay in the ratio 3:3:2 (v/v/v). The substratum was amended with $25 \mathrm{~g}$ per $\mathrm{kg}$ of rock phosphate (SIARKOPOL, Tarnobrzeg). Prior to seedling transfer, ca. $15 \mathrm{~g}$ of AM fungal inoculum containing propagules of $G$. intraradices UNIJAG.PL24-1 isolated from a grassland close to Inowroclaw (Poland) was introduced below the seedlings. Inoculum was produced in 3-L pots of sterile substratum (sand/expanded clay 2:1,v/v) with Zea mays and Plantago lanceolata as host plants. After 4 months of cultivation, the shoots were harvested and the inoculum was dried for 30 days. Inoculum quality was assessed on P. lanceolata

Table 1 List of transgenic plants investigated

\begin{tabular}{|c|c|c|c|c|}
\hline Transgenic line & Origin of gene & Type of gene and gene construct & $\begin{array}{l}\text { Method of gene introduction } \\
\text { and selection }\end{array}$ & References \\
\hline W92.40 & Petunia hybrida & $\begin{array}{l}\text { CHS, CHI, DFR, triple gene } \\
\text { construct, each under } \\
35 \mathrm{~S} \text { promoter }\end{array}$ & $\begin{array}{l}\text { Agrobacterium mediated } \\
\text { transformation, PCR, } \\
\text { Northern blot }\end{array}$ & Lorenc-Kukuła et al. 2005 \\
\hline GT4, GT5 & Solanum sogarandinum & SsGT1 gene under nap promoter & $\begin{array}{l}\text { Agrobacterium mediated } \\
\text { transformation, PCR, } \\
\text { Northern blot }\end{array}$ & Lorenc-Kukuła et al. 2009 \\
\hline M50 & Ralstonia eutropha & $\begin{array}{l}\text { phbA, phbB, phbC, triple gene } \\
\text { construct, phbB and C genes } \\
\text { under } 35 \mathrm{~S}, \text { phbA } \\
\text { under } 14-3-3 \text { promoter }\end{array}$ & $\begin{array}{l}\text { Agrobacterium mediated } \\
\text { transformation, PCR, } \\
\text { Northern blot }\end{array}$ & Wróbel et al. 2004 \\
\hline B14 & Solanum tuberosum & $\begin{array}{l}\text { beta-1,3-glucanase gene } \\
\text { under } 35 \mathrm{~S} \text { promoter }\end{array}$ & $\begin{array}{l}\text { Agrobacterium mediated } \\
\text { transformation, PCR, } \\
\text { Northern blot }\end{array}$ & Wróbel-Kwiatkowska et al. 2004 \\
\hline
\end{tabular}


seedlings grown for 6 weeks; inoculation resulted in over $90 \%$ AMF colonized root length.

The pots were placed in Sunbags (Sigma) and flax plants were grown under greenhouse conditions: $25 / 18^{\circ} \mathrm{C}$ maximum/minimum average air temperatures, $12 \mathrm{~h}$ light supplemented if needed $\left(200 \mu \mathrm{mol} \times \mathrm{m}^{-2} \times \mathrm{s}^{-1}\right.$ PAR $)$. Plants were irrigated weekly with distilled water and once per 3 weeks with Long Ashton solution (Davies et al. 1992). After 3month growth, when plants started to form flowers, photosynthesis was measured and plants were harvested. Length of roots and shoots and dry weight of shoots were estimated (roots were used for estimation of mycorrhizal parameters).

\section{Mycorrhizal colonization}

Roots were washed, cleared in $10 \% \mathrm{KOH}$ for $24 \mathrm{~h}$ at room temperature and, after rinsing in tap water, acidified for $1 \mathrm{~h}$ in $5 \%$ lactic acid then stained $24 \mathrm{~h}$ at room temperature in $0.05 \%$ aniline blue in lactic acid, in order to visualize the fungal structures inside the roots. One-centimeter root pieces were mounted on slides in lactoglycerol (approx. 45 root pieces per plant) and mycorrhizal parameters in root systems were assessed according to Trouvelot et al. (1986; http://www2.dijon.inra.fr/mychintec/Mycocalc-prg/ download.html): frequency of mycorrhiza presence $(F \%)$, intensity of mycorrhizal colonization $(M \%)$, and arbuscule abundancy $(A \%)$. Images were acquired using a NIKON Eclipse E800 microscope equipped with DIC, a digital image capture system and a computer image analysis system.

\section{Plant growth assessment}

Shoot length was measured, then material was dried for 2 days at $40^{\circ} \mathrm{C}$ and weighed (Radwag analytical balance, WPA 60/c/1). Mycorrhizal dependency (Md) of plants for growth (mass, shoot length) as well as performance index (see below) was determined according to the equation given by van der Heijden and Sanders (2002)

$\mathrm{P}$ and $\mathrm{Zn}$ concentrations in plants

Dried, grinded, and homogenized flax shoots were digested in 10-mL concentrated (65\%) nitric and perchloric acids (Ultranal, POCh) according to Pilegaard (1979). Residues were dissolved in $10 \mathrm{~mL} 0.2 \%$ nitric acid, filtered, and diluted if necessary. Zinc concentrations were analyzed by flame atomic absorption spectrometry using AAnalyst 200, Perkin-Elmer. Nitric acid was used as a blank and Ulva lactuca BCR-279 as a standard reference material (Promochem $\mathrm{GmbH} ; \mathrm{Zn}=51.3 \mathrm{mg} \mathrm{kg}^{-1}$ ). Concentrations of phosphorus were determined by flow injection analysis system (FIA) coupled with flow colorimeter (FIA compact, MLE $\mathrm{GmbH})$.

\section{Fluorescence measurements}

Chlorophyll $a$ fluorescence transients of intact leaves were measured with a plant efficiency analyzer fluorimeter (Hansatech Instruments, UK) and recorded as described by Strasser et al. (1995). Each transient was analyzed according to the OJIP test (Strasser et al. 2004, 2007) and the following biophysical parameters (referring to time point zero) were calculated to characterize PSII behavior: (1) specific energy fluxes per reaction center for absorption (ABS/RC); (2) electron trapping (TRo/RC), electron dissipation (DIo/ $\mathrm{RC}$ ), and electron transport (To/RC); (3) the flux ratios or yields, i.e., the maximum quantum yield of primary photochemistry $\left(\varphi_{\mathrm{Po}}=\mathrm{TRo} / \mathrm{ABS}\right) ;(4)$ the efficiency with which a trapped exciton can move an electron into the electron transport chain further than $Q_{\mathrm{A}}\left(\psi_{0}=\mathrm{ET}_{0} / \mathrm{TR}_{0}\right)$, the quantum yield of electron transport $\left(\varphi_{E o}=\mathrm{ET0} / \mathrm{ABS}\right) ;(5)$ and the performance index (PI), which provides quantitative information about the state of plants and their vitality. The latter incorporates three independent expressions: (1) ratio of reaction center chlorophylls and the total chlorophyll of PSII; (2) an expression related to primary photochemistry $\phi \mathrm{Po} /(1-\phi \mathrm{Po})$; and (3) an expression related to electron transport $\Psi_{\mathrm{o}} /\left(1-\Psi_{\mathrm{o}}\right)$ (Oukarroum et al. 2007).

\section{Data analysis}

Data from mycorrhizal and nonmycorrhizal plants were compared using the $t$ test or were transformed with decimal logarithms prior to analysis to meet statistical assumptions and compared using ANOVA, STATISTICA (ver. 7.0) software (significance level $P<0.05$ ).

\section{Results}

\section{AMF colonization}

Arbuscular mycorrhiza of Arum type with well-developed arbuscules were observed in all inoculated flax plants. These structures were not found in any of the non-inoculated samples. The frequency of mycorrhiza $(F \%)$, reflecting propagule density in the samples, ranged from $93 \%$ to $100 \%$ and showed the smallest differences between root samples among studied parameters. The intensity of mycorrhizal colonization ( $M \%$ ) ranged from $40 \%$ to $65 \%$. Significantly higher $M \%$ values were noted in the case of lines B14 and W92.40, while other transformed lines from the cultivars Linola and Nike were similar (Fig. 1). The largest differences between samples involved arbuscule abundancy $(A \%)$ in roots which was highest in the two transgenic lines W9240 and B14. The other lines derived from cv. Linola showed similar values for arbuscule abundancy. In contrast, 


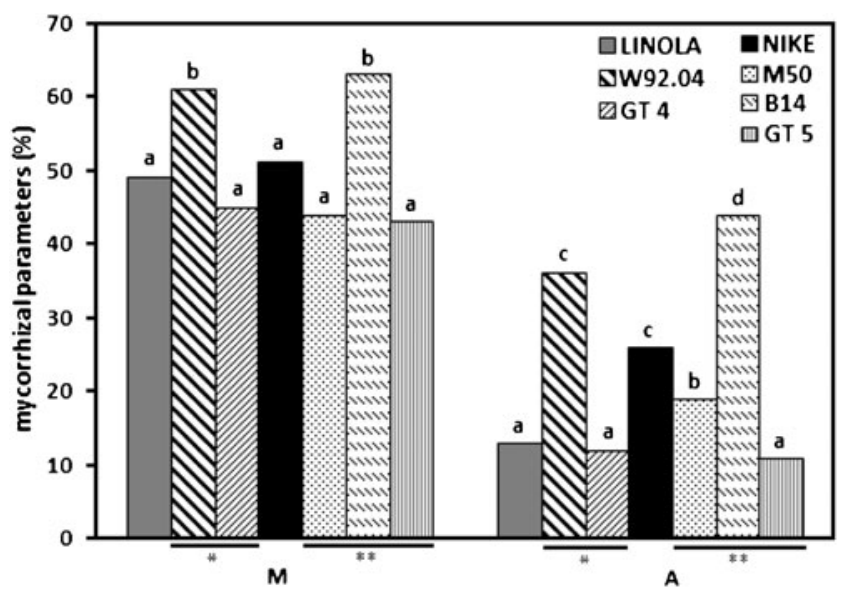

Fig. 1 Relative mycorrhizal intensity $(M)$ and relative arbuscule richness (A) in L. usitatissimum; the numbers represent percent values, according to the parameter definitions by Trouvelot et al. (1986); asterisk - GM lines of Linola, double asterisks - GM lines of Nike; bars labeled with the same letter are not significantly different at $P<0.05$

the GM lines derived from cv. Nike either had higher (B14) or significantly lower (M50) A\% (Fig. 1). Roots were free of parasites or nematodes.

Plant growth and performance

Mycorrhizal plants of cv. Nike and Linola were characterized by increased total biomass and root weight in comparison to nonmycorrhizal controls (Fig. 2). Smaller but still significant differences $(P=0.049)$ were found in root or shoot weight between mycorrhizal and nonmycorrhizal GM lines. There were no significant differences between shoot weight of mycorrhizal transgenic lines and of their parent cultivars. In the case of root weight, statistically significant differences were found only between GT4 and cv. Linola (Fig. 2). Among nonmycorrhizal plants, higher shoot weight was found in GT4 than in cv. Linola and lower weight in B14 than in cv. Nike, while the root weight of W92.40 and GT4 were 3 and 2 times higher than in cv. Linola, respectively, and in M50 and GT5 were over 1.5 and 2 times higher than in cv. Nike. Md for growth was higher in cv. Nike (30\%) than in cv. Linola (18\%). Transformation of these two cultivars resulted in decreased values of growth $\mathrm{Md}$ in comparison to the parent cultivars. Negative values were found in the lines W92.40 $(-18 \%)$, GT4 $(-14 \%)$, and GT5 $(-12 \%)$, while the Md value of B14 was ca. $10 \%$ lower than in cv. Nike.

$\mathrm{P}$ concentration in flax shoots was significantly higher in mycorrhizal plants than in nonmycorrhizal ones, both in GM lines and parent cultivars, except for line M50 (Fig. 3a). On the contrary, Zn concentration depended on the flax cultivar, being significantly increased in cv. Linola, but not in cv. Nike. No significant differences were found in two modified lines, B14 and W92.40 (Fig 3b). No significant differences in $\mathrm{Md}$ concerning $\mathrm{P}$ and $\mathrm{Zn}$ were found between GM and non-GM lines. No differences were found in flowering time of the GM and non-GM lines or between mycorrhizal and nonmycorrhizal plants.

The measure of plant performance, PI, revealed differences between transgenic lines and the parent cultivars. PI of mycorrhizal plants of cultivars Nike and Linola were significantly higher than in nonmycorrhizal ones (Fig. 3). Md estimated on the basis of plant performances (PI) in these two cultivars were $12 \%$ and $26 \%$, respectively.

Among transformed lines, a similar situation was found only in the case of W92.04 ( $\mathrm{Md}=21 \%)$; a negative effect of mycorrhization on PI was not significant in the case of GT4 $(\mathrm{Md}=-17 \%)$, while in other cases the values were similar in mycorrhizal and nonmycorrhizal plants (Fig. 4). In addition, PI increase in non-transformed cultivars following mycorrhization was associated with statistically significant differences in several PSII parameters, such as ABS/RC, TRo/ $\mathrm{RC}$, DIo/RC, and $\mathrm{To} / \mathrm{RC}$, the maximum quantum yield of primary photochemistry $\left(\varphi_{\mathrm{Po}}=\mathrm{TRo} / \mathrm{ABS}\right)$, and the quantum yield of electron transport $\left(\varphi_{E o}=\mathrm{ET} 0 / \mathrm{ABS}\right)$ (data not shown). This was not the case for transgenic lines where PI in mycorrhizal plants was not significantly different from nonmycorrhizal ones (GT4, M50, B14, and GT5).
Fig. 2 Shoot (a) and root (b) dry weight (in grams) of mycorrhizal $(M)$ and nonmycorrhizal $(N M)$ plants; asterick - GM lines of Linola, double asterisks - GM lines of Nike; different letters above columns indicate statistically significant differences $(P<0.05)$
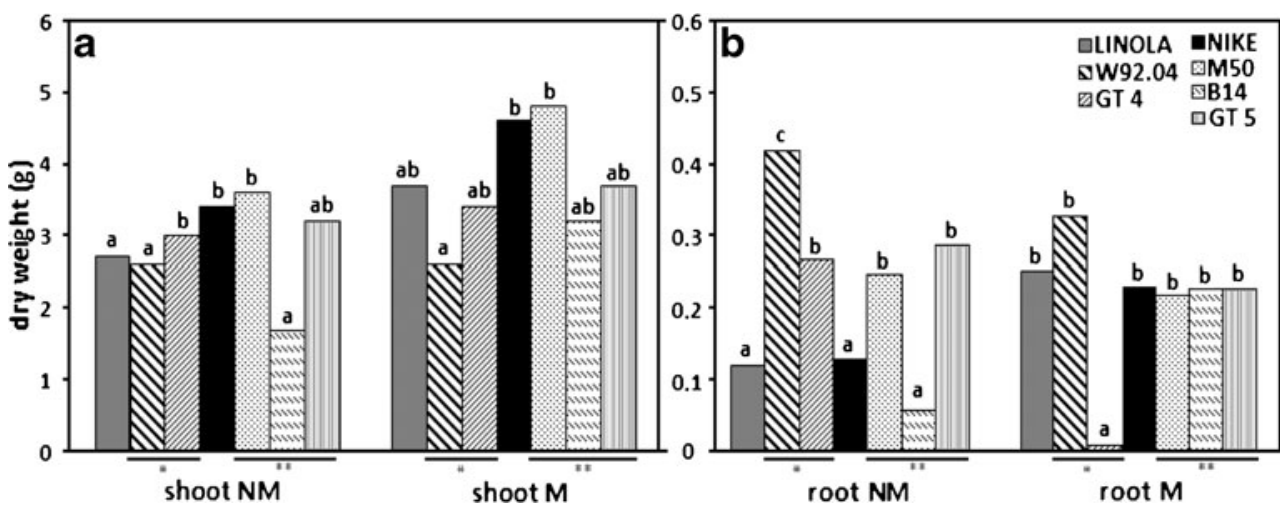
Fig. 3 Comparison of P (a) and $\mathrm{Zn}$ (b) concentration in mycorrhizal $(M)$ and nonmycorrhizal $(N M)$ shoots; asterick - GM lines of Linola, double asterisks - GM lines of Nike; bars labeled with different letters are significantly different at $P<0.05$

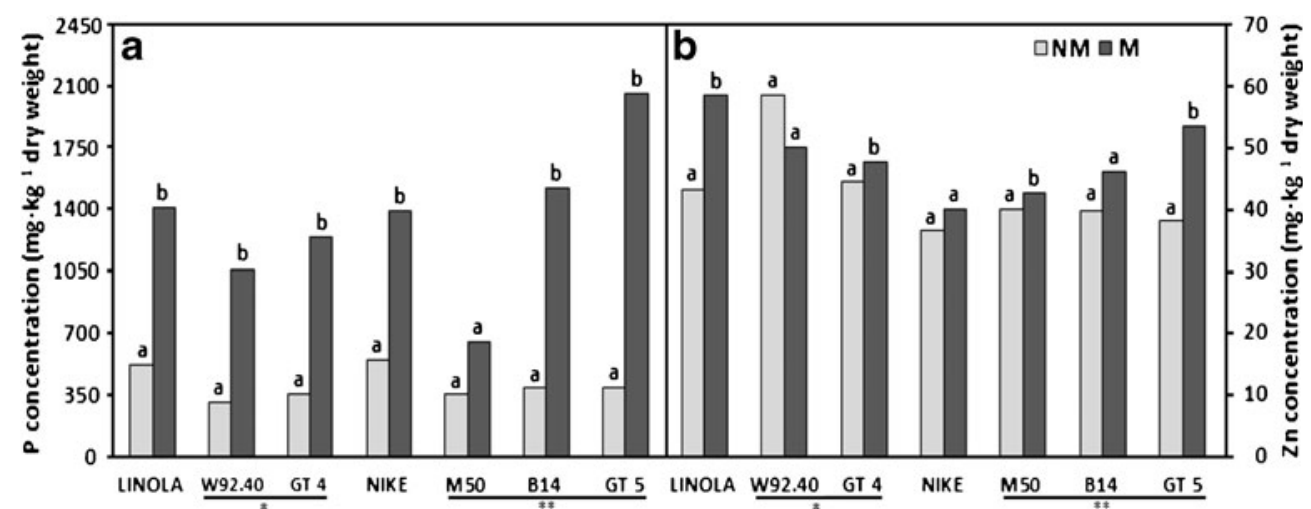

\section{Discussion}

AMF root colonization in flax has been previously described (Dickson et al. 2003; Vierheilig et al. 2008) and effects of the symbiosis on non-modified flax have been the subject of both field (Thingstrup et al. 1998; Olsson et al. 1999) and laboratory (Püschel et al. 2008; Rydlova et al. 2010) studies. Mycorrhizal effects have been shown on flax growth, due to increased uptake of $\mathrm{P}$ and $\mathrm{Zn}$ by fungal mycelium (Thompson 1994; Thingstrup et al. 1998; Smith et al. 2004), on fiber weight, seed production, and fatty acid composition of seed oils (Rydlova et al. 2010), on drought resistance (Druge and Schonbeck 1992; von Reichenbach and Schonbeck 1995) and on resistance to plant pathogens (Dugassa et al. 1996). The main aim of the present study was to determine whether genetic transformation of flax by different resistance-related genes affects AMF and/or their effects on host performance. Transformation did not change the degree of mycorrhizal colonization; no morphological differences were found between transformed and nontransformed flax lines and arbuscules, which are indicative of a functional symbiosis, were well developed in all cases

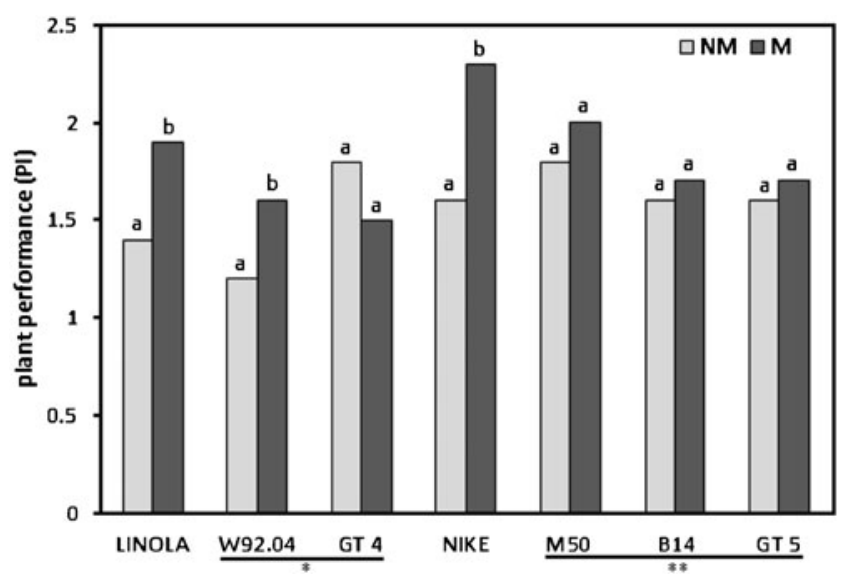

Fig. 4 Comparison of plant performance $(P I)$ between mycorrhizal $(M)$ and nonmycorrhizal $(N M)$ plants - $t$ test; asterisk-GM lines of Linola, double asterisks - GM lines of Nike; bars labeled with different letters are significantly different at $P<0.05$ except line M50. The lines B14 and W92.40 showed even higher arbuscule abundancy in comparison with the parent cultivars. These observations are in agreement with most of previously published data showing no negative effect on fungal growth in plants overexpressing defense-related genes (Liu 2010). The transformations in the present flax lines increase resistance to pathogenic fungi via increased phenylpropanoid levels (W92.40) (Lorenc-Kukula et al. 2005), antioxidant capacity (W92.40, GT) and overproduction of glycosyltransferase (GT) (Lorenc-Kukuła et al. 2004) and $\beta-1,3$-glucanase ectopic expression of a potato $\beta-1,3$-glucanase gene in flax (B14). Since there is some similarity between the soil-borne pathogens and AMF in their resources such as space and photosynthate within the root, such defense "pathways" could be potentially deleterious to both groups of fungi (Whipps 2004). However, as reviewed by Dumas-Gaudot et al. (2000) and Khan et al. (2010), AMF are capable themselves of inducing hydrolytic enzymes and pathogenesis-related proteins without being affected. For example, AMF are not inhibited by Class I chitinases (Arlorio et al. 1991; Salzer et al. 1997; Vierheilig et al. 1993) that are deleterious to pathogenic fungi such as Rhizoctonia solani. Similarly, AMF are not affected by an antifungal protein that targets Verticillium albo-atrum or Botrytis cinerea in transformed aubergine plants (Turrini et al. 2004a, b). This differential targeting of pathogenic and mycorrhizal fungi could be due to mechanisms of recognition specificity (Vierheilig et al. 2008; Khan et al. 2010; Stefani and Hamelin 2010) but this issue requires further indepth research.

The effect of genetically modified crops on mycorrhizal fungi has so far been mostly addressed by analysis of mycorrhizal colonization levels which, as mentioned above, are largely unaffected. However, the present data indicate that, although growth of the mycorrhizal transformed flax plants was not different from the parent lines, transformation may alter plant responses to AMF which could be relevant for biomass production and crop quality under agricultural conditions. While no significant differences were observed in Md concerning $\mathrm{P}$ and $\mathrm{Zn}$, G. intraradices was less 
effective in stimulating growth or photosynthetic performance and, in one case P uptake (M50), by transformed as compared to parent flax plants. The magnitude of mycorrhizal responses can be influenced not only by the plant but also environmental factors (Smith and Gianinazzi-Pearson 1988, Smith and Read 2008, Jakobsen et al. 2002). In the GM flax lines, the lower mycorrhizal dependency parameters in reference to plant growth and photosynthesis efficiency resemble the situation between modern varieties or landraces and their ancestors (Hetrick et al. 1992, 1993; Boyetchko 1996), and both might be less adapted to an agriculture turned towards low fertilizer inputs, especially in phosphorus and nitrogen, where AMF can be the key players in establishment of ecosystem function and diversity (Thompson 1994, van der Heijden et al. 1998, Klironomos et al. 2000).

In conclusion, it was shown that the genes introduced into flax lines to increase resistance against pathogens did not have a negative effect on the colonization of flax by AMF but may affect some plant responses to the symbiosis. Plant growth and photosynthetic activity were not significantly improved by $G$. intraradices in the transformed as compared to parent lines, but $\mathrm{P}$ nutrition was still enhanced in all but one which may be promising for better survival of seedlings due to better nutrition of seeds. The fact that the transformed flax lines, which meet the demands for better quality of fiber and higher resistance to pathogens, do not appear to be negatively affected in their interactions with AMF should make them suitable for use in agriculture.

Acknowledgments We greatly acknowledge Dr. Anna Jurkiewicz (Aarhus University, DK) for the comments on the manuscript. This study was supported by grants SPUB/COST 870 (197/N-COST/2008/0), NN 302061834, and NR 12-0009-06 from the Ministry of Science and Higher Education.

Open Access This article is distributed under the terms of the Creative Commons Attribution Noncommercial License which permits any noncommercial use, distribution, and reproduction in any medium, provided the original author(s) and source are credited.

\section{References}

Arlorio M, Ludwig A, Boller T, Mischiati P, Bonfante P (1991) Effects of chitinase and $\beta-1,3$ glucanase from pea on the growth of saprophytic, pathogenic and mycorrhizal fungi. Giorn Bot Ital 125:956-959

Armstrong GM, Armstrong JK (1981) Formae speciales and races of Fusarium oxysporum causing wilt diseases. In: Nelson PE, Toussoun TA, Cook RJ (eds) Fusarium: Diseases, biology and taxonomy. The Pennsylvania State University Press, University Park, pp 392-399

Boyetchko SM (1996) Impact of soil microorganisms on weed biology and ecology. Phytoprotection 77(1):41-56

Czemplik M, Boba A, Kostyn K, Kulma A, Mituła A, Sztajnert M, Wróbel- Kwiatkowska M, Żuk M, Szopa J, SkórkowskaTelichowska K (2011) Flax engineering for biomedical application in biomedical engineering. In: Komorowska MA, OlsztyńskaJanus S (eds) Trends, research and technologies. Intechweb Org, Rijeka, pp 407-434

Davies FT, Potter JR, Linderman GR (1992) Mycorrhiza and repeated drought exposure affect drought resistance and extraradical hyphae development of pepper plants independent of plant size and nutrient content. J Plant Physiol 139:289-294

Dickson S, Schweiger P, Smith FA, Söderström B, Smith S (2003) Paired arbuscules in the Arum-type arbuscular mycorrhizal symbiosis with Linum usitatissimum. Can J Bot 81:457-463

Drüge U, Schönbeck F (1992) Effect of vesicular-arbuscular mycorrhizal infection on transpiration, photosynthesis and growth of flax (Linum usitatissimum L.) in relation to cytokinin levels. J Plant Physiol 141:40-48

Dugassa GD, von Alten H, Schoneck F (1996) Effects of arbuscular mycorrhiza (AM) on health of Linum usitatissimum L. infected by fungal pathogen. Plant Soil 185(2):173-182

Dumas-Gaudot E, Gollotte A, Cordier C, Gianinazzi S, GianinazziPearson V (2000) Modulation of host defence systems. In: Arbuscular mycorrhizas: Physiology and function. Dordrecht, Kluwer Academic, pp 173-200

Giovannetti M, Sbrana C, Turrini A (2005) The impact of genetically modified crops on soil microbial communities. Riv Biol-Biol Forum 98:393-418

Gredes T, Dominiak M, Gedrange T, Kunert-Keil C, WróbelKwiatkowska M, Szopa J (2010) The influence of biocomposites containing genetically modified flax fibers on gene expression in rat skeletal muscle. Biomedizinische Technik. Biomed Eng 55 (6):323-329

He X, Nara K (2007) Element biofortification: can mycorrhizas potentially offer a more effective and sustainable pathway to curb human malnutrition? Trends Plant Sci 12(8):331-333

Hetrick BAD, Wilson GWT, Cox TS (1992) Mycorrhizal dependence of modern wheat cultivars, landraces and ancestors. Can J Bot 70:2032-2040

Hetrick BAD, Wilson GWT, Cox TS (1993) Mycorrhizal dependence of modern wheat cultivars and ancestors: a synthesis. Can J Bot 71:512-518

Jakobsen I, Smith SE, Smith FA (2002) Function and diversity of arbuscular mycorrhizas in carbon and mineral nutrition. In: van der Heijden MGA, Sanders IR (eds) Mycorrhizal ecology. Springer, Berlin, pp 75-92

Jhala AJ, Raatz LL, Dexter JE, Hall LM (2010) Adventitious presence: volunteer flax (Linum usitatissimum) in herbicide-resistant canola (Brassica napus). Weed Technol 24:244-252

Jones JP (1991) Fusarium wilt. In: Jones JB, Stall RE, Zitter TA (eds) Compendium of tomato diseases. APS, St Paul

Khan HMD, Meghvansi MK, Panvar V, Gogoi HK, Singh L (2010) Arbuscular mycorrhizal fungi-induced signaling in plant defence against phytopathogens. J Phytol 2(7):53-69

Klironomos JN, McCune J, Hart M, Neville J (2000) The influence of arbuscular mycorrhizae on the relationship between plant diversity and productivity. Ecol Lett 3(2):137-141

Liu W (2010) Do genetically modified plants impact arbuscular mycorrhizal fungi? Ecotoxicology 19:229-238

Lorenc-Kukula K, Amarowicz R, Oszmianski J, Doermann P, Starzycki M, Skala J, Zuk M, Kulma A, Szopa J (2005) Pleiotropic effect of phenolic compounds content increases in transgenic flax plant. J Agric Food Chem 53:3685-3692

Lorenc-Kukuła K, Kostyń K, Łukaszewicz M, Szopa J (2004) Glucosyltransferase, the gene arrangement and enzyme function. Cel Mol Biol 9:935-946

Lorenc-Kukuła K, Zuk M, Kulma A, Czemplik M, Kostyn K, Skała J (2009) Engineering flax with the GT family 1 Solanum sogarandinum glycosyltransferase SsGT1 confers increased resistance to Fusarium infection. J Agric Food Chem 57(15):6698-6705 
Łukaszewicz M, Matysiak-Kata I, Skała J, Fecka I, Cisowski W, Szopa J (2004a) Antioxidant capacity manipulation in transgenic potato tuber by changes in phenolic compounds content. J Agric Food Chem 52:1526-1533

Łukaszewicz M, Szopa J, Krasowska A (2004b) Susceptibility of lipids from different flax cultivars to peroxidation and its lowering by added antioxidants. Food Chem 88:225-231

Olsson PA, Thingstrup I, Jakobsen I, Bååth E (1999) Estimation of the biomass of arbuscular mycorrhizal fungi in a linseed field. Soil Biol Biochem 31(13):1879-1887

Oukarroum A, El Madidi S, Schansker G, Strasser RJ (2007) Probing the responses of barley cultivars (Hordeum vulgare L.) by chlorophyll $a$ fluorescence OLKJIP under drought stress and rewatering. Environ Exp Bot 60:438-446

Pilegaard K (1979) Heavy metals in bulk precipitation and transplanted Hypogymnia physodes and Dicranoweisia cirrata in the vicinity of a Danish steelworks. Water Air Soil Poll 11:77-91

Püschel D, Rydlová J, Sudová R, Gryndler M (2008) Cultivation of flax in spoil-bank clay: mycorrhizal inoculation vs. high organic amendments. J Plant Nutr Soil Sci 171(6):872-877

Ren X (2006) Effect of Bt transgenic rice (KMD) on soil bacterial community and rhizosphere AM fungi. Dissertation, Zhejiang University. Hang Zhou, China

Rydlová J, Püschel D, Sudová R, Gryndler M, Mikanová O, Vosátka M (2010) Interaction of arbuscular mycorrhizal fungi and rhizobia: effects on flax yield in spoil-bank clay. J Plant Nutr Soil Sc 174:128-134

Salzer P, Hübner B, Sirrenberg A, Hager A (1997) Differential effect of purified spruce chitinases and B-1,3-glucanases on the activity of elecitors from ectomycorrhizal fungi. Plant Physiol 114:957-968

Skórkowska-Telichowska K, Żuk M, Kulma A, Bugajska-Prusak A, Ratajczak K, Gąsiorowski K, Kostyn K, Szopa J (2010) New dressing materials derived from transgenic flax products to treat long-standing venous ulcers - a pilot study. Wound Rep Reg 18:168-179

Smith SE, Gianinazzi-Pearson V (1988) Physiological interactions between symbionts in vesicular arbuscular mycorhizal plants. Annu Rev Plant Phys 39:211-244

Smith SE, Read DJ (2008) Mycorrhizal symbiosis. Academic, London

Smith SE, Smith FA, Jakobsen I (2004) Functional diversity in arbuscular mycorrhizal (AM) symbioses: the contribution of the mycorrhizal P uptake pathway is not correlated with mycorrhizal responses in growth or total P uptake. New Phytol 162:511-524

Stefani FOP, Hamelin RC (2010) Current state of genetically modified plant impact on target and non-target fungi. Environ Rev 18:441-475

Strasser RJ, Srivastava A, Govindjee (1995) Polyphasic chlorophyll a fluorescence transient in plants and cyanobacteria. Photochem Photobiol 61:32-42

Strasser RJ, Tsimilli-Michael M, Srivastava A (2004) Analysis of the chlorophyll $a$ fluorescence transient. In: Papageorgiou GC, Govindjee (eds) Chlorophyll $a$ fluorescence: A signature of photosynthesis, advances in photosynthesis and respiration series (Govindjee-Series Editor) vol 19. Kluwer Academic, Rotterdam, pp 321-362

Strasser RJ, Tsimilli-Michael M, Dangre D, Rai M (2007) Biophysical phenomics reveals functional building blocks of plants systems biology: a case study for the evaluation of the impact of mycorrhization with Piriformospora indica. In: Varma A, Oelmuller R (eds) Advanced techniques in soil biology. Soil Biology Series. Springer, Germany, pp 220-221
Szopa J, Wróbel-Kwiatkowska M, Kulma A, Zuk M, SkórkowskaTelichowska K, Dymińska L, Mączka M, Hanuza J, Zebrowski J, Preisner M (2009) Chemical composition and molecular structure of fibers from transgenic flax producing polyhydroxybutyrate, and mechanical properties and platelet aggregation of composite materials containing these fibers. Compos Sci Technol 69:24382446

Thingstrup I, Rubaek G, Sibbesen E, Jakobsen I (1998) Flax (Linum usitatissimum L.) depends on arbuscular mycorrhizal fungi for growth and $\mathrm{P}$ uptake at intermediate but not high soil $\mathrm{P}$ levels in the field. Pant Soil 203:37-46

Thompson JP (1994) Inoculation with vesicular-arbuscular mycorrhizal fungi from cropped soil overcomes long-fallow disorder of linseed (Linum usitatissimum L.) by improving $\mathrm{P}$ and $\mathrm{Zn}$ uptake. Soil Biol Biochem 26:1133-1144

Trouvelot A, Kough JL, Gianinazzi-Pearson V (1986) Mesure du taux de mycorhization VA d'un systeme radiculaire. Recherche de methodes d'estimation ayant une signification fonctionnelle. In: Gianinazzi-Pearson V, Gianinazzi S (eds) Physiological and genetical aspects of Mycorrhizae. INRA, Paris, pp 217 221

Turrini A, Sbrana C, Nuti MP, Pietrangeli BM, Giovannetti (2004a) Development of a model system to assess the impact of genetically modified corn and aubergine plants on arbuscular mycorrhizal fungi. Plant Soil 266:69-75

Turrini A, Sbrana C, Pitto L, Ruffini Castiglione M, Giorgetti L, Briganti R, Bracci T, Giovannetti M (2004b) The antifungal Dm-AMP1 protein from Dahlia merckii expressed in Solanum melongena is released in root exudates and differentially affects pathogenic fungi and mycorrhizal symbiosis. New Phytol 163 (2):393-403

Van der Heijden MGA, Klironomos JN, Ursic M, Moutoglis P, Streitwolf-Engel R, Boller T, Wiemken A, Sanders IR (1998) Mycorrhizal fungal diversity determines plant biodiversity, ecosystem variability and productivity. Nature 396:69-72

Van der Heijden MGA, Sanders IR (2002) Mycorrhizal Ecology. Springer, Berlin

Vierheilig H, Alt M, Neuhaus JM, Boller T, Wiemken A (1993) Colonization of transgenic Nicotiana sylvestris plants, expressing different form of Nicotiana tabacum chitinase, by the root pathogen Rhizoctonia solani and by the mycorrhizal symbiont Glomus mosseae. Mol Plant-Microbe Interact 6:261-264

Vierheilig H, Steinkellner S, Khaosaad T, Garcia-Garrido JM (2008) The biocontrol effect of mycorrhization on soilborne fungal pathogens and the autoregulation of the AM symbiosis: one symbiosis, two effects? In: Varma A (ed) Mycorrhiza. SpringerVerlag, Berlin, pp 307-320

von Reichenbach HG, Schönbeck F (1995) Influence of VAmycorrhiza on drought tolerance of flax (Linum usitatissimum L.). II. Effect of VA mycorrhiza on stomatal gass exchange, shoot water potential, phosphorus nutrition and the accumulation of stress metabolites. Angew Bot 69:183-188

Whipps JM (2004) Prospects and limitations for mycorrhizas in biocontrol of root pathogens. Can J Bot 82(8):1198-1227

Wróbel M, Zebrowski J, Szopa J (2004) Polyhydroxybutyrate synthesis in transgenic flax. J Biotechnol 107:41-54

Wróbel-Kwiatkowska M, Lorenc-Kukula K, Starzycki M, Oszmianski J, Kepczynska E, Szopa J (2004) Expression of $\beta$-1,3-glucanase in flax causes increased resistance to fungi. Physiol Mol Plant Pathol 65:245-256 